\title{
Extended Development Work to Validate a HLW Calcine Waste Form Via INL's Cold Crucible Induction Melter
}

James A. King Vince C. Maio

September 2011

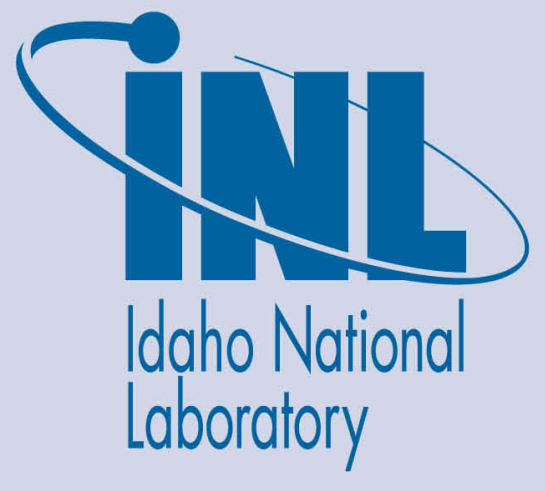

The INL is a U.S. Department of Energy National Laboratory operated by Battelle Energy Alliance 
INL/EXT-11-23388

\title{
Extended Development Work to Validate a HLW Calcine Waste Form Via INL's Cold Crucible Induction Melter
}

\author{
James A. King \\ Vince C. Maio
}

September 2011

Idaho National Laboratory

Idaho Falls, Idaho 83415

http://www.inl.gov

Prepared for the

U.S. Department of Energy

Assistant Secretary for Environmental Management

Under DOE Idaho Operations Office

Contract DE-AC07-05ID14517 


\section{DISCLAIMER}

This information was prepared as an account of work sponsored by an agency of the U.S. Government. Neither the U.S. Government nor any agency thereof, nor any of their employees, makes any warranty, expressed or implied, or assumes any legal liability or responsibility for the accuracy, completeness, or usefulness, of any information, apparatus, product, or process disclosed, or represents that its use would not infringe privately owned rights. References herein to any specific commercial product, process, or service by trade name, trade mark, manufacturer, or otherwise, does not necessarily constitute or imply its endorsement, recommendation, or favoring by the U.S. Government or any agency thereof. The views and opinions of authors expressed herein do not necessarily state or reflect those of the U.S. Government or any agency thereof. 


\section{ABSTRACT}

To accomplish high level waste (HLW) calcine treatment objectives, the Idaho Clean-up Project contractor at the Idaho National Laboratory (INL), CWI, has chosen to immobilize the calcine in a glassceramic via the use of a Hot-Isostatic-Press (HIP). The choice for HIPing has been formally documented in a 2010 Record of Decision (ROD). Even though the HIP process may prove suitable for the calcine as specified in the ROD and validated in a number of past value engineering sessions, DOE is evaluating back-up treatment methods for the calcine as a result of the technical, schedule, and cost risk associated with the HIPing process. Consequently DOE-HQ has requested DOE-ID to make INL's bench-scale coldcrucible induction melter (CCIM) available for investigating its viability as a process alternate to calcine treatment.

Providing a solid, stable, low volume and durable material that can be easily stored and/or disposed is the rationale for the immobilization of radioactive waste material (i.e. HLW calcine) in either a glass, ceramic, or glass-ceramic form. In addition, the waste form is the most controllable of the key components in immobilizing and isolating radioactive waste in a deep geological repository. In general ceramic and glass-ceramics waste forms offer an alternative to the traditional borosilicate glass HLW forms. Ceramics typically accommodate higher waste loadings than borosilicate glass, leading to smaller intermediate and long-term disposal facilities. Many ceramic phases are known to possess superior chemical durability as compared to borosilicate glass due to their similarity to natural analog minerals that geologically contain natural actinides. However, pure ceramics are generally multiphase systems containing many minor phases that make characterization and prediction of performance challenging within a repository environment. Therefore, many investigators have proposed using glass-ceramics as a compromise between the more inexpensive, easier to characterize glass waste forms and the more durable ceramic waste forms. Glass-ceramics have several advantages over traditional borosilicate glasses as a waste form. Borosilicate glasses can inadvertently denitrify, leading to a less durable product that could crack during cooling and unwanted crystals may be prone to dissolution. By designing glass-ceramics, the risks of deleterious effects from devitrification are removed. Glass-ceramics should provide a waste form with the advantages of both glass and ceramics - ease of manufacture (especially via the CCIM) with improved mechanical properties, thermal stability, and chemical durability.

The INL's bench-scale CCIM is a unique technology that is extremely well suited for the generation of all these types of waste forms, especially glass-ceramics. The CCIM's attributes, if validated through testing, may provide a calcine waste form and a corresponding waste process that results in high waste form durability, loading, throughput, and robustness; all of which may be equivalent or superior to the HIPing process and the glass-ceramic calcine waste form it produces. As such, this report emphasizes the aspects relevant for the validation of the CCIM's use in the production of glass-ceramic waste forms for all classes of INL HLW calcine. 


\section{CONTENTS}

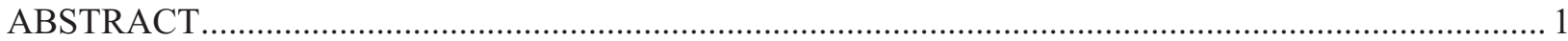

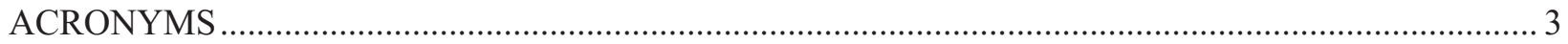

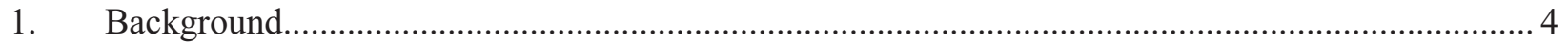

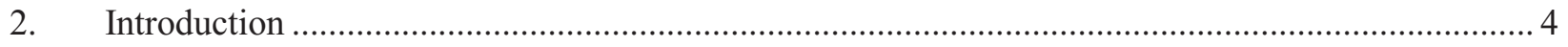

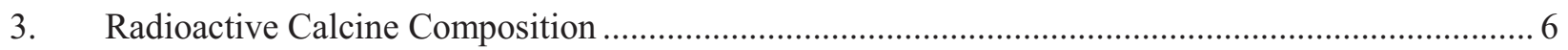

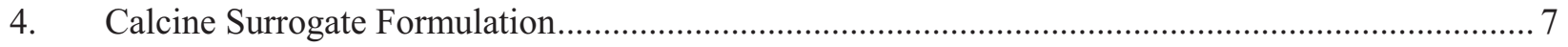

$4.1 \quad \mathrm{~T}-2$ Non-Radioactive Calcine .................................................................................... 7

Modifications Required for T-2 Calcine to Prepare Calcine Surrogates
Representative of all Classes..................................................................................... 8

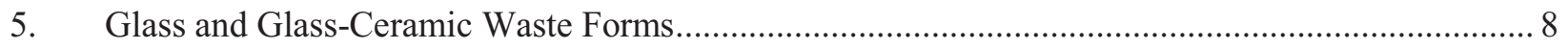

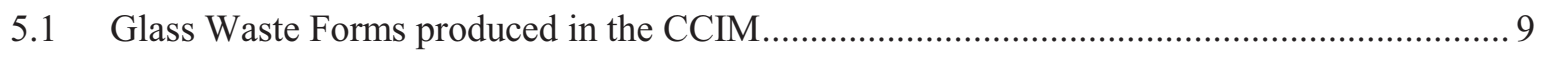

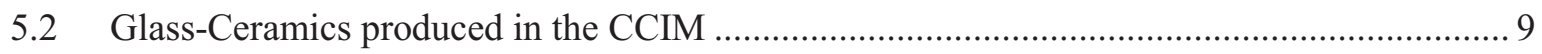

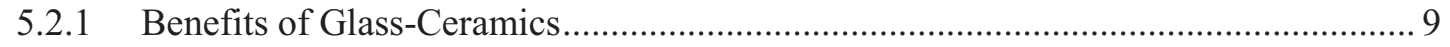

5.2.2 Glass-Ceramic Waste Form Production.................................................................. 10

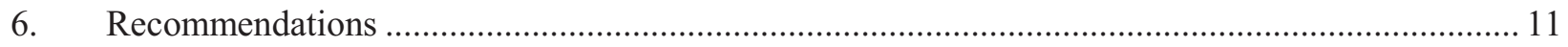

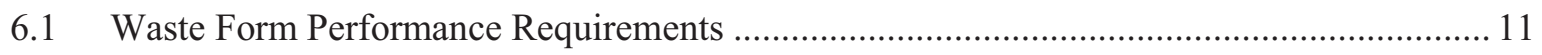

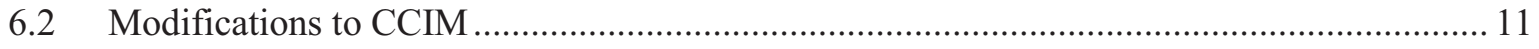

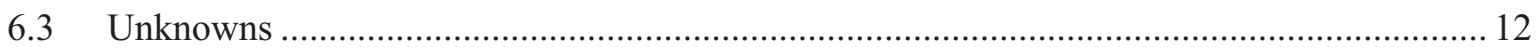

6.3.1 Throughput to be Competitive with HIP Processing .......................................... 12

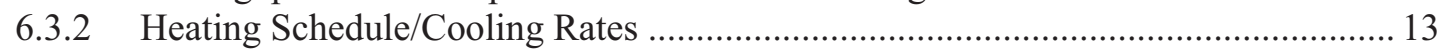

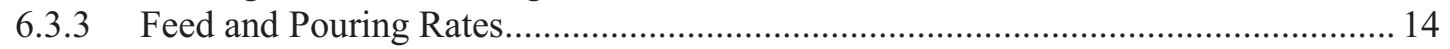

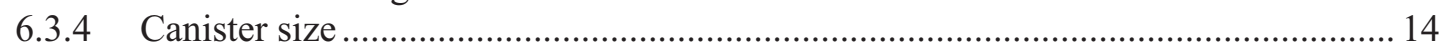

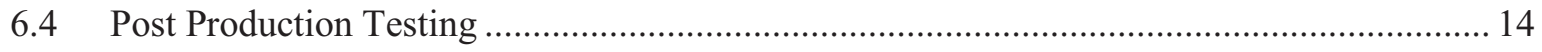

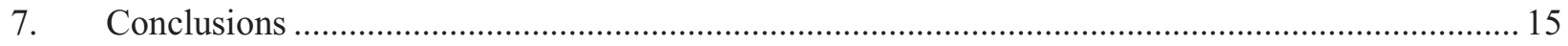

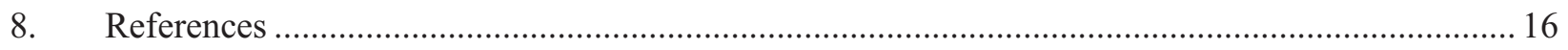

\section{FIGURES}

Figure 1. Simplified Schematic of the Major INL Bench scale CCIM System. ........................................5

Figure 2. Photo of the INL CCIM during a Melt Drain. ......................................................................... 5

\section{TABLES}

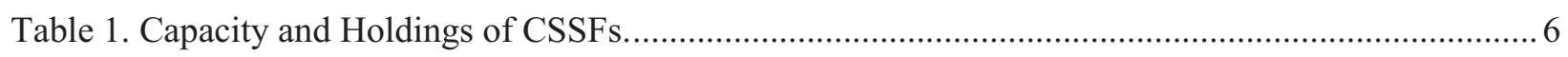

Table 2. Chemical Contents of the Four Types of INTEC calcines......................................................... 7 


\title{
ACRONYMS
}

\author{
BEA Battelle Energy Alliance \\ BSG Borosilicate Glass \\ CCIM Cold Crucible Induction Melter \\ CSSF Calcine Solid Storage Facility \\ DOE Department of Energy \\ EM US DOE Department of Environmental Management \\ FSU Former Soviet Union \\ HIP Hot Isostatic Press \\ HLW High-Level- Waste \\ ICP Idaho Clean-up Project \\ IEDF INL Engineering Demonstration Facility \\ INL Idaho National Laboratory \\ IWTU Idaho Waste Treatment Unit \\ JHM Joule Heated Melter \\ NWCF New Waste Calcining Facility \\ PCT Product Consistency Test \\ RCRA Research Conservation and Recovery Act \\ ROD Record of Decision \\ SRS Savannah River Site \\ TCLP Toxic Characteristic Leaching Procedure
}




\section{Extended Extended Development Work to Validate a HLW Calcine Waste Form via INL's Cold Crucible Induction Melter}

\section{Background}

The Department of Energy's (DOE's) Idaho National Laboratory (INL) — through its clean-up contractor attached to the Idaho Clean-up Project (ICP) - is required under a State of Idaho agreement to remove and treat, for eventual disposal, over $4,000 \mathrm{~m}^{3}$ of solid radioactive High-Level-Waste (HLW) calcine by 2035. The HLW calcine was generated as a result of reprocessing defense and unique nuclear reactor fuels for over 40 years. Since the reprocessing method was an aqueous technique, the calcine was generated by solidifying the liquid raffinate in a de-nitrating fluidized bed to a particulate with an average diameter of $\sim 3 \mathrm{~mm}$. Even though the calcine step reduced the HLW raffinate volume by over eight fold, the calcine, which is currently stored in six different vaulted bin sets, is not acceptable for direct disposal in any future HLW/spent fuel repository. As such, the calcine must be properly immobilized to contain its fission products, long-term alpha emitting radionuclides (unrecovered actinides and transuranics) and hazardous RCRA metals.

To accomplish the calcine treatment objectives, the Idaho Clean-up Project contractor, CWI, has chosen to immobilize the calcine in a glass-ceramic via the use of a Hot-Isostatic-Press (HIP); a treatment selection formally documented in a 2010 Record of Decision (ROD) [1,2]. The HIP process is currently under both development and design and present plans call for adding HIPing via modifications to the Idaho Waste Treatment Unit (IWTU) [3], a facility recently constructed for treating liquid radioactive tank waste. Even though the HIP process may prove suitable for the calcine as specified in the ROD and validated in a number of past value engineering sessions, DOE is evaluating back-up treatment methods for the calcine as a result of the technical, schedule, and cost risk associated with the HIPing process. Consequently DOE-HQ has requested DOE-ID to make INL's bench-scale cold-crucible induction melter (CCIM) available for investigating its viability as a process alternate to calcine treatment. With that backdrop, this document provides a generalized report for CCIM testing of all classes of simulated nonradioactive calcine in INL's bench scale CCIM, with the major objective of generating glass-ceramic waste forms for the HLW calcine. A test plan involving one class of surrogate calcine for exploration of phosphate-based glass waste forms to be generated in the CCIM has been developed [4] and discussions concerning the CCIM vitrification of all calcine classes are not extensively covered in this report.

\section{Introduction}

The INL's bench-scale Cold Crucible Induction melter (CCIM) is located in Idaho Falls, Idaho at the DOE's Idaho Engineering Development Facility- IEDF (Pilot-Plant test bay number 1) and will be the location of the potential calcine/glass ceramic tests described in this plan. Details of the bench scale CCIM and its unique technology can be found in various references (examples: [5, 6]) and are not being provided here. For general information a simplified schematic of the major CCIM systems is shown in Figure 1 below and a photo of the 10.25-inch diameter CCIM crucible (showing induction coils) during the draining of melted glass/waste is shown in Figure 2. Both figures highlight the major design features that provide improvements over the conventional Joule Heated Melters (JHM) currently in wide use for HLW. These features include the induction coils, which eliminate in-bed electrodes subject to high corrosion and the vertical cooling tubes that make up the crucible wall, which in turn create a solid glass skull layer at the crucible wall that negates the need for corrosive refractory. 


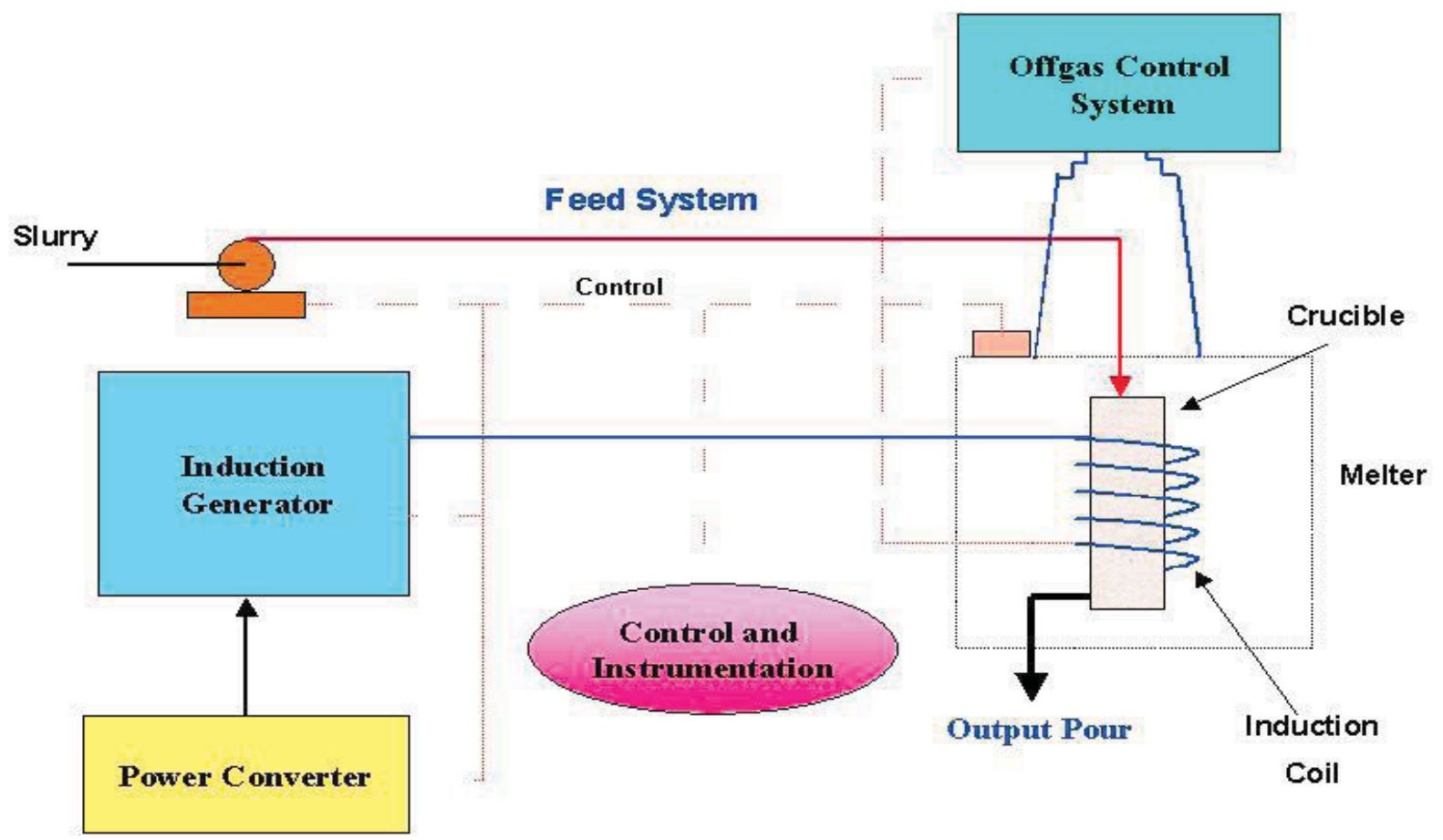

Figure 1 Simplified Schematic of the Major INL Bench scale CCIM System.

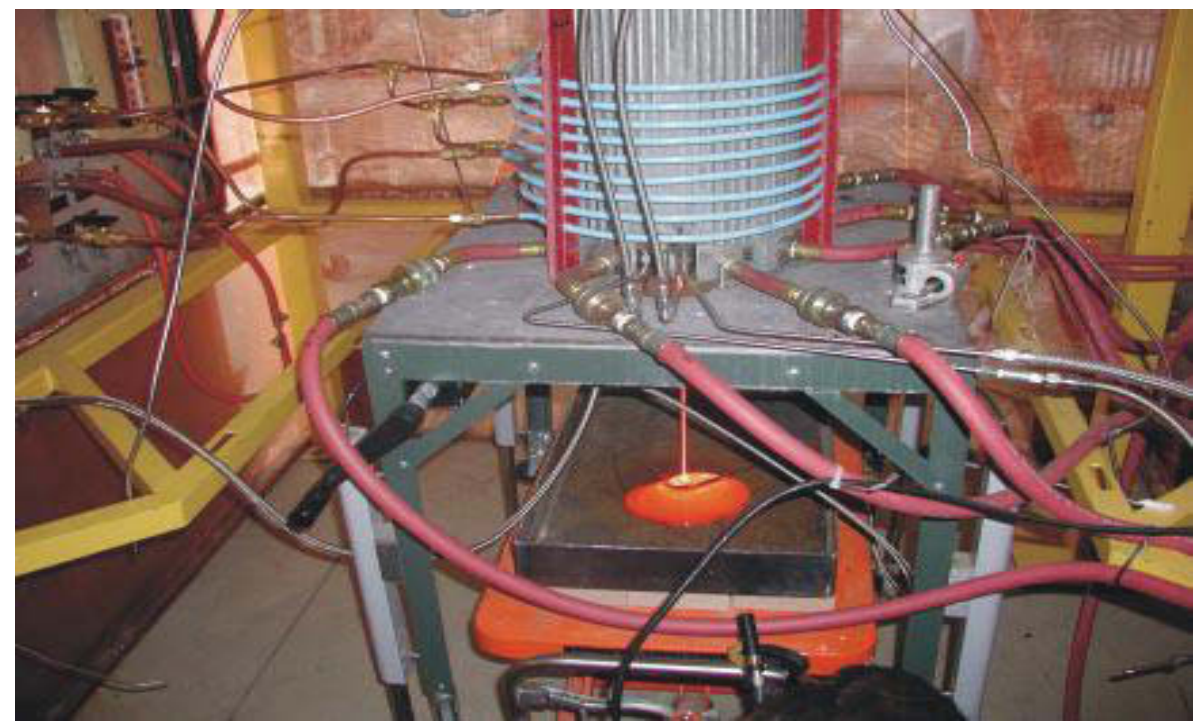

Figure 2 Photo of the INL CCIM during a Melt Drain.

Operated by the Battelle Energy Alliance (BEA) since 2003, the CCIM is the only cold-wall induction melter used for waste processing in the United States. The CCIM is a unique design as opposed to the traditional Joule-heated design. The latter design is being utilized at DOE's Savannah River Site (SRS) and will be deployed at DOE's Hanford site to vitrify defense liquid HLW into glass. However, past and present testing in CCIM pilot plants and international full-scale operations in France, South Korea, and the Former Soviet Union (FSU) indicate some clear advantages of the CCIM over the conventional JHMs, all of which may prove beneficial for the calcine waste. These benefits are a direct result of the CCIM's unique design features (i.e., no electrodes or melter refractory exposed to corrosion at high temperatures) that provide for higher temperature melter operations up to $2000^{\circ} \mathrm{C}$ as compared to 
$1000^{\circ} \mathrm{C}$ in the JHM. As a result, higher HLW loadings, greater waste throughputs and smaller footprints for the melter space are potentially achievable with the CCIM relative to the JHM. As such, if $\mathrm{CCIM} /$ calcine glass-ceramic tests prove acceptable in the performance objectives outlined below, the CCIM may be an acceptable cost, schedule, and technically risk adverse alternative to the baseline calcine treatment option (i.e., HIPing).

\section{Radioactive Calcine Composition}

Knowledge of the radioactive calcine composition is important for designing plans for validating a waste form via the CCIM. Information on the radioactive calcine was obtained from an Idaho National Engineering and Environmental Laboratory Report (INEEL/EXT-98-00455 Rev. 3) on the calcined waste stored at the Idaho Nuclear Technology and Engineering Center [7]. Tables are recreated from this report and their findings are summarized in this section.

From December 1963 until May 2000, aqueous nuclear fuel reprocessing waste (i.e., first cycle raffinate) was calcined to a solid form in fluidized beds. The waste was heated to $400-600^{\circ} \mathrm{C}$ where it underwent thermal decomposition to metal oxides, fluorides, nitrogen oxides, or water vapor. The solids from this process were transported to a Calcine Solid Storage Facility (CSSF) for temporary storage. Each CSSF is composed of several stainless storage bins within a concrete vault. Currently there are six CSSFs (i.e., Bin sets) with radioactive calcine storage; five at near capacity and one partially filled. A summary of capacity and holdings of the six CSSFs is given in Table 1.

Table 1 Capacity and Holdings of CSSFs.

\begin{tabular}{|c|c|c|c|c|}
\hline $\begin{array}{c}\text { CSSF } \\
\text { Facility }\end{array}$ & $\begin{array}{c}\text { Total } \\
\text { volume } \mathrm{ft}^{3}\end{array}$ & $\begin{array}{c}\text { Useable } \\
\text { volume } \mathrm{ft}^{3}\end{array}$ & $\begin{array}{c}\text { Filled volume } \\
\mathrm{ft}^{3}\left(\mathrm{~m}^{3}\right)\end{array}$ & $\%$ Full \\
\hline I & 8,300 & 8,000 & $7,760(220)$ & 97 \\
\hline II & 31,600 & 30,000 & $30,000(851)$ & 100 \\
\hline III & 40,000 & 39,900 & $39,500(1120)$ & 99 \\
\hline IV & 17,700 & 17,100 & $17,200(487)$ & 100 \\
\hline V & 36,200 & 35,600 & $35,600(1010)$ & 100 \\
\hline VI & 55,200 & 53,200 & $25,200(713)$ & 47 \\
\hline
\end{tabular}

Few historical calcine samples with extensive analysis were performed. Obtaining additional representative calcine samples from the CSSFs would be difficult and costly and may not provide reliable composition data due to the heterogeneity of the calcine. Further complicating the question of the calcine composition is the fact that the calcine within the CSSF bins is not homogenous and cannot be mixed. Each bin is likely to contain multiple layers of chemically and radiologically distinct material.

Additionally, within the six CSSFs there are a total of 43 bins each containing six to 12 sections, resulting in different calcine compositions. Therefore, sampling to determine a representative composition is cost prohibitive. Thus, the composition of the calcine stored in CSSFs is estimated from operating data of waste calcining facilities including volume and composition of liquid waste calcined, operation of the CSSFs, and other INTEC fuel and waste processing information. Calcine composition corresponds to the liquids treated in the calciner and the base material added to calciner.

Over the 30 years of operation, various calciner chemistries were used to treat varying liquid HLWs from reprocessing; therefore the radioactive calcine stored in CSSF vaults is comprised of many different compositions. Liquid wastes and corresponding calcines are typically named for the cladding of nuclear fuel from with they came and/or the principle waste component [7]. Calcining campaigns treated liquid wastes from the reprocessing of a variety of spent nuclear fuels from numerous reactors. Differences in 
fuel cladding dictated the use of different chemicals for dissolution and reprocessing: such as nitric acid, hydrofluoric acid, mercury, chromium, and cadmium. Reprocessing these various fuels resulted in chemically different liquid wastes producing chemically different calcines. However, the entire existing radioactive HLW calcine stored in the 6 bin sets at the INL can be classified into four broad categories for CCIM test purposes; zirconium oxide based, aluminum oxide based, zirconium/sodium blend and a calcine consisting of an aluminum nitrate/sodium blend. For most cases, the classification corresponds to the cladding metal of the original reprocessed fuel.

Calcine compositions are calculated by the historical processing model (HPM). The "HPM uses the composition and volumes of the liquid wastes that were calcined, CSSF bin filling history and temperature data, ORIGEN2-based radioactivity calculations, calciner operating history, and other fuel and waste processing data to calculate the calcine composition" [7]. The typical chemical content of the four most common calcine classes is shown in Table 2.

Table 2 Chemical Contents of the Four Classes of INTEC (INL) calcines.

\begin{tabular}{|c|c|c|c|c|c|}
\hline \multirow[b]{2}{*}{$\begin{array}{c}\text { Chemical } \\
\text { Species }\end{array}$} & \multirow[b]{2}{*}{ Units } & \multicolumn{4}{|c|}{ Type of Calcine } \\
\hline & & Aluminum* & Zirconium* & $\begin{array}{c}\text { Zirconium } \\
\text { (Fluorinel) / Sodium } \\
\text { Blend* }\end{array}$ & $\begin{array}{c}\text { Aluminum } \\
\text { Nitrate /Sodium } \\
\text { Blend* }\end{array}$ \\
\hline Aluminum & $\mathrm{wt} \%$ & 47.0 & 11.0 & 5.0 & 37.0 \\
\hline Boron & $\mathrm{wt} \%$ & 0.3 & 1.0 & 1.0 & 0.1 \\
\hline Cadmium & $\mathrm{wt} \%$ & & & 5.5 & 0.2 \\
\hline Calcium & $\mathrm{wt} \%$ & & 25.0 & 28.0 & 3.2 \\
\hline Chloride & $\mathrm{wt} \%$ & & & 0.1 & 0.4 \\
\hline Chromium & $\mathrm{wt} \%$ & 0.1 & 0.3 & 0.1 & 0.1 \\
\hline Fluoride & $\mathrm{wt} \%$ & & 27.0 & 18.0 & 1.8 \\
\hline Iron & $\mathrm{wt} \%$ & 0.1 & 0.3 & 0.3 & 0.6 \\
\hline Mercury & $\mathrm{wt} \%$ & 2.1 & & & \\
\hline Nitrate & $\mathrm{wt} \%$ & 4.3 & 0.1 & 6.7 & 6.1 \\
\hline Oxygen & $\mathrm{wt} \%$ & 42.0 & 17.0 & 15.0 & 37.0 \\
\hline Potassium & $\mathrm{wt} \%$ & 0.3 & 0.1 & 0.8 & 1.9 \\
\hline Sodium & $\mathrm{wt} \%$ & 2.2 & & 3.3 & 8.6 \\
\hline Sulfate & $\mathrm{wt} \%$ & 1.0 & & 3.5 & 0.3 \\
\hline Tin & $\mathrm{wt} \%$ & & 0.3 & 0.2 & \\
\hline Zirconium & $\mathrm{wt} \%$ & & 18.0 & 12.0 & 1.4 \\
\hline
\end{tabular}

\section{Calcine Surrogate Formulation}

\subsection{T-2 Non-Radioactive Calcine}

The calcine simulant to be used in the CCIM glass test run referenced in this report [4] is only representative of the HLW aluminum nitrate/sodium blend calcine that is in INL bin set 6 . This calcine test in the CCIM will be performed in a manner to make phosphate based glass as opposed to a glass ceramic (as discussed below) for the other major calcine classes

The simulant to be used for the phosphate glass test will be obtained from $\sim 20,500 \mathrm{kgs}$ of stored nonradioactive calcine that was formulated during the 1982 cold start-up of the (now shut down) INL New 
Waste Calcining Facility (NWCF). This cold calcine which is $\sim 64 \%-76 \%$ aluminum oxide and $1 \%-6.1 \%$ dolomite was removed from the NWCF prior to NWCF "hot" operations and then stored in one of two temporary buildings. As such it has been given the designation of T-2 calcine. In particular, the T-2 is a mixture of startup bed dolomite (containing calcium/magnesium oxides and carbonates) and 3 different feeds. The three feeds were similar in that they were primarily aluminum nitrate, with varying amounts of sodium nitrate and some boron oxide.

\subsection{Modifications Required for T-2 Calcine to Prepare Calcine Surrogates Representative of all Classes}

In terms of radioactive calcine volume, about $75 \%$ is zirconium based and the remaining $25 \%$ is about equal amounts of aluminum based and the aluminum nitrate/sodium blend. As such, the T-2 calcine is representative of only $12-13 \%$ of the total calcine inventory (i.e., the aluminum nitrate/sodium blend). Additionally, no RCRA metals were used in making the T-2 calcine.

To appropriately simulate the calcines stored in CSSFs it will be necessary to spike T-2 calcine with a composition similar to the radioactive calcine as well as ensure sufficient levels of zirconium and aluminum oxide. T-2 calcine must be spiked with RCRA metals and since the T-2 calcine is not radioactive, it is necessary to add an actinide surrogate to ensure that formulations will partition the radioactive components to the ceramic phase within the glass-ceramic. Neodymium has been used as a surrogate for plutonium and trivalent minor actinides previously in studies focused on glass-ceramics, at up to $6.27 \mathrm{wt} \%$ neodymium oxide [8-12]. The radioactive calcine has $\leq 400 \mathrm{ppm}$ Uranium, $\leq 400 \mathrm{ppm}$ Cesium, and $0.003 \mathrm{wt} \%{ }^{90} \mathrm{Sr}$, thus a neodymium oxide concentration of $\sim 1.2 \mathrm{wt} \%$ would approximate the concentration of actinides in the radioactive calcine. Surrogate calcine compositions of cadmium at a concentration of 55, $000 \mathrm{ppm}$ [5.5 wt \%] will be achieved by spiking the T-2 calcine with amorphous cadmium oxide to reflect the composition of the actual HLW calcine and ensure the objectives of the CCIM test run are achieved.

\section{Glass and Glass-Ceramic Waste Forms}

The waste form is the key component for the immobilization and long-term isolation of radioactive waste. Providing a solid, stable, and durable waste form with high calcine waste loadings( with a reliable and efficient process) that can be temporarily stored and indefinitely disposed is the rationale for the immobilization of HLW calcine [13]. Immobilization is accomplished by either chemical dissolution within the atomic structure of the waste form matrix or encapsulation within the inert matrix. A viable waste form must have the ability to incorporate radioactive elements within its chemical structure and remain stable and chemically durable over geologic time frames [14]. The maximum waste loading for a given waste form will dictate the size of the intermediate and long-term storage/disposal facility[13].

Many DOE legacy wastes contain high concentrations of materials that are difficult to incorporate into glass waste forms. Examples of problematic materials include plutonium and other actinides, technetium, calcium, fluoride, sulfate, chloride, phosphate, and high concentrations of alumina, zirconium, cesium, strontium, mercury, cadmium, organics and PCBs [15]. As noted above the radioactive calcine stored in CSSFs contain high concentrations of zirconium which promotes crystal formation and fluoride which negatively impacts viscosity and corrosivity of the melt. The high alumina concentrations can lead to refractory-based corrosive melts that tend toward crystallization of nepheline [16]. Combined these could lead to glass waste forms with poor durability or glass waste forms with unacceptable waste loadings. 


\subsection{Glass Waste Forms produced in the CCIM}

The immobilization of HLW by vitrification is a well established process that is in current deployment and has been extensively investigated over the last 60 years. Many different glass types have been proposed as potential candidates for immobilization of radioactive wastes, but the current standard is borosilicate glass or BSG. Many commercial vitrification plants are in operation around the world using borosilicate glass to immobilize HLW [13].

The main advantages of vitrification of the HLW calcine classes in the CCIM include the following: glass is a good solvent for most all the constituents in the calcine, glass can be processed at reasonable low temperatures, glass is tolerant to variations in waste composition, glass shows acceptable chemical durability, and glass is radiation resistant and can accommodate some changes during radioactive decay [13]. The choice of a glass composition waste form is a compromise amongst HLW solubility, low leachability in repository environments, and the temperature at which the glass is formed. Suitable glass forms make it possible to incorporate up to 25-30 wt. \% HLW into a glass [13]. There have been several reports using CCIM technology to develop glass waste forms, for example [17-19].

\subsection{Glass-Ceramics produced in the CCIM}

\subsubsection{Benefits of Glass-Ceramics}

Ceramic and glass ceramic waste forms offer an attractive alternative to traditional borosilicate glass (or a phosphate-based glass) waste forms and, if proven to be formable in the CCIM, may result in a calcine waste form with equivalent loadings and durability to those created via HIPing. Pure ceramics (i.e., waste forms made up of single or multiple phases of only synthetic crystalline minerals) can usually accommodate higher waste loadings than borosilicate glass [13], leading to smaller intermediate and longterm storage/disposal facilities. Many ceramic phases are known to possess superior chemical durability as compared to borosilicate glass [13]. However, ceramics are generally multiphase systems containing many minor phase that make characterization and prediction of performance within a repository challenging. Additionally, the technologies employed in ceramic manufacture are typically more complex and expensive. Thus, many investigators have proposed using glass-ceramics as a compromise between in the more inexpensive, easier to characterize glass waste forms and the more durable ceramic waste forms. Glass-ceramics have several advantages over traditional borosilicate glasses as a waste form. Borosilicate glasses can inadvertently devitrify, leading to a less durable product that could crack during cooling and crystals may be prone to dissolution. By designing a glass-ceramics, the risks of deleterious effects from devitrification are removed. Furthermore, glass-ceramics have higher mechanical strength and impact strengths [20] and possess greater chemical durability as noted above. Glassceramics should provide a waste form with the advantages of glass - ease of manufacture - with improved mechanical properties, thermal stability, and chemical durability [21].

Zirconolite $\left(\mathrm{CaZrTi}_{2} \mathrm{O}_{7}\right)$ has long been recognized as a suitable to ceramic crystalline host for actinides since Uranium and Plutonium are incorporated into the $\mathrm{Ca}$ and $\mathrm{Zr}$ sites as tetravalent ions [13, 22]. Zirconolite is a crystalline phase that is chemically durable and radiation resistant and has a high capacity to incorporate actinides and lanthanides within its crystal lattice [13]. Due to the high concentrations of $\mathrm{ZrO}_{2}$ in the radioactive calcine (see table 2) the production of a glass-ceramic containing zirconolite is recommended. In addition to zirconolite, many other crystalline phases are suitable for the very long-term tie-up of actinides. Examples of the many others, that may or may not be suitable for the HLW calcine classes, include the crystalline ceramics of: pyrochlore, apatite, zircon, monazite, and baddeleyite. 


\subsubsection{Glass-Ceramic Waste Form Production}

Glass-ceramics are partially crystalline solids prepared by the partial devitrification of precursor glass [20]. The preparation of useful glass-ceramics is accomplished with a better understanding of the nucleation and growth of crystals within glass. Once the waste form has been cast, crystallization is accomplished by an additional heat treatment schedule. This schedule can include controlled cooling to nucleation temperature for initial crystallization followed by heating or holding at temperature for crystal growth. For glass-ceramics designed for nuclear waste the volume fraction of residual glass is typically $>$ $50 \%$, which yields discreet crystalline structures within the vitreous matrix [20].

Several demonstrations of glasses with ceramic phases within them have been completed using CCIM technology [15, 23-25]. A CCIM has been used at full scale (crucible inside diameter $=418 \mathrm{~mm}$ with a melt height $\sim 860 \mathrm{~mm}$ ) in the former Soviet Union to make glass-ceramic waste forms from simulated Savannah River samples $[24,25]$. Several of these tests had waste loadings up to $60 \% \mathrm{wt}$.

A study on the formation of glass-ceramics using a CCIM has been performed with calcines simulating those stored in CSSFs [23]. This study focused efforts on formulating a glass-ceramic that could accommodate a wide range of waste compositions while limiting potential for volatility of some radionuclides and pouring into standard US canisters. Key to developing a suitable glass-ceramic waste form is the formulation of the base glass and cooling schedule. While information of the base glass is not included, Day et al. evaluated 400 different formulations/cooling scenarios and showed, using simulated INL calcine, that the formation of major crystalline phases (Zirconolite, rutile, zirconia, and fluorite) was not very sensitive to the cooling rate [23].

Several papers from Loiseau, Caurant, and coworkers have explored different glass-ceramic formulations and their influence for the crystallization of Zirconolite and partitioning of Neodymium (i.e., the actinide surrogate ) into the crystalline (i.e., the ceramic) phases [8-12, 26, 27]. In two papers [11, 12], Loiseau and coworkers started with an alumniosilicate glass $\left(\mathrm{SiO}_{2}-\mathrm{Al}_{2} \mathrm{O}_{3}-\mathrm{CaO}\right)$ and varied the recipe by changing the weight (molar) percentage of $\mathrm{CaO}, \mathrm{TiO}_{2}$ and $\mathrm{ZrO}_{2}$ added to the melts. This represents an excellent starting point for production of glass-ceramics using INL calcine, since as previously discussed (Table 2), it contains a high concentration of $\mathrm{Al}_{2} \mathrm{O}_{3}$ and $\mathrm{ZrO}_{2}$. After melting and pouring the glassy matrix, the glass was annealed at $750{ }^{\circ} \mathrm{C}$, prior to promoting crystallization at $850^{\circ} \mathrm{C}$. Different heat schedules were used for each of the three glass compositions (all with crystallization temperature above transformation temperature) to explore how temperature altered crystallization. This work showed that different formulations have different responses to different heat schedules, but zirconolite was the only crystalline phase formed in the bulk of the glass with crystallization temperatures of $1050^{\circ}$ and $1200^{\circ} \mathrm{C}$. Furthermore, the wt $\%$ of $\mathrm{CaO}, \mathrm{TiO}_{2}$ and $\mathrm{ZrO}_{2}$ increased the volume fraction of zirconolite crystals and the incorporation of $\mathrm{Nd}$ within zirconolite. When comparing nucleation temperatures, $1050^{\circ} \mathrm{C}$ was more consistent for incorporation of $\mathrm{Nd}$ within zirconolite than $1200^{\circ} \mathrm{C}$. Caurant, Loiseau, and coworkers also evaluated the effects of increased $\mathrm{Al}_{2} \mathrm{O}_{3}$ content on the crystallization of zirconolite [9]. With their additive formulation it was shown that increased $\mathrm{Al}_{2} \mathrm{O}_{3}$ increased the nucleation of zirconolite crystals in the bulk and increased the incorporation of Neodymium into the zirconolite phase. Thus, the high concentration of $\mathrm{Al}_{2} \mathrm{O}_{3}$ in the radioactive calcine may help increase nucleation of zirconolite crystals and partitioning of actinides to this phase. Additionally, they show that at nucleation temperatures of $1050^{\circ}$ and $1200^{\circ} \mathrm{C}$ zirconolite is the only crystalline phase in bulk within the $\mathrm{SiO}_{2}-\mathrm{Al}_{2} \mathrm{O}_{3}-\mathrm{CaO}$ glass formulation [9]. 


\section{Recommendations}

It is recommended that several different CCIM tests be performed to evaluate the formation of glassceramics using at least 2 of the major classes of INL simulated calcines (i.e., zirconium and aluminum oxide based). These tests should be broken up into two separate tasks: (1) identification of an additive composition starting with $\mathrm{SiO}_{2}-\mathrm{Al}_{2} \mathrm{O}_{3}-\mathrm{CaO}$ glass that will accomplish the goals listed in section 6.1 and (2) demonstration of CCIM processing to further explore the effects of heat schedules (annealing, nucleation temperature, crystallization temperature, and hold times), waste loading, and feed/pour rates. Specific efforts should be focused on minimizing volatility of the melt, including cesium. This will allow for techno-economic analysis to determine if CCIM production of glass-ceramics is a viable fall back technology for calcine treatment.

\subsection{Waste Form Performance Requirements}

A desired list of qualities for a glass-ceramic waste form is given below:

- Due to the variability of the radioactive calcine (Table 2), the ability to accommodate a wide range of waste compositions is necessary.

- To minimize costs associated with the waste form, it should be able to accommodate high waste loadings $\geq 50 \% \mathrm{wt}$.

- The glass-ceramic waste form should have an additive formulation that:

○ Minimizes volatility of the melt, including cesium.

- Allows for pouring into canisters and controlled canister cooling to ensure formation of the correct glass-ceramic phases.

- Where possible (as determined by the composition of the waste) minimizes the number of phases within the glass-ceramic.

- Quality compatible with disposal into future geologic facilities with clear qualification requirements that eliminate past requirements that were not technically supported since they were based on the long time periods associated with the alpha decay of the remaining actinides in the calcine. Since the ceramic portion of the glass-ceramic is considered to be more durable than the surrounding glass, one quality indicator may be the same as what is used for glass, PCT leach testing.

- Maintains quality over a wide range of cooling scenarios, by avoiding the formation of crystal phases detrimental to the waste form such as nepheline $\left[\mathrm{NaAlSiO}_{4}\right]$, anorthite $\left[(\mathrm{Ca}, \mathrm{Na})(\mathrm{Si}, \mathrm{Al})_{4} \mathrm{O}_{8}\right]$, and nosean $\left[\mathrm{Na}_{8} \mathrm{Al}_{6} \mathrm{Si}_{6} \mathrm{O}_{24} \mathrm{SO}_{4}\right]$.

\subsection{Modifications to CCIM}

Prior to operating the CCIM for simulated radioactive calcine, there are a number of critical modifications that must be completed if formation of a glass ceramic waste form is possible, they are as follows:

- Removal of the current CCIM liquid simulant feed system.

- Design, installation, and testing of a dry solid feed system suitable for dry feeding the calcine surrogate.

- Design and installation of dry auger feed system access and vents to ensure minimal and regulatory compliant worker exposure to the RCRA hazardous metal(s) in the dry particulate feed that constitutes the surrogate calcine. 
- Resetting of the CCIM's radio frequency generator frequency to ensure inductive coupling of the generated magnetic field to the unique electrical resistivity of the surrogate calcine and the glassceramic frits and additives

- Revision of the approved Laboratory Instruction in a manner to accommodate for the hazards associated with a particulate feed containing RCRA hazardous metals.

- CCIM melter drain and melt collection canister modifications and associated temperature control equipment as needed to ensure the post melt heating /cooling rates necessary to form the proper glass -ceramic phases

\subsection{Unknowns}

While operating the CCIM in the future for the purpose of validating a glass-ceramic waste form for the calcine, besides waste form quality, additional data should be collected to preliminary assess if the CCIM technology is even operationally feasible for the INL's IWTU. This data will support, in part, the first unknown addressed in this section. Latter unknowns addressed include issues of CCIM melt pouring and post melt heat treatment

\subsubsection{Throughput to be Competitive with HIP Processing}

Approximately 12,200,000 lbs of radioactive calcine are stored in CSSF vaults at INTEC. This waste must be treated and readied for transport out of Idaho by December 31, 2035, as required by the Idaho Settlement Agreement [28]. A 2009 modification to the CWI contract states that the design and processing of radioactive calcine "shall be based on treatment (if required), packaging, and shipment/storage of all HLW within a 12-year period" [29]. To prepare the 12.2 million pounds within this time frame will require processing approximately 3,980 lbs of HLW calcine per day:

It is assumed that glass-ceramic produced within the CCIM to accommodate a loading of at least 50\% calcine, thus in total (additives + calcine) the throughput from CCIM must be approximately 7,960 lbs per day:

Several groups have published throughputs of their CCIM on a mass per time per area basis, for example [18, 30-32]. Stefanovsky, et al., give a process throughput rate of $890 \mathrm{~kg} / \mathrm{m}^{2} / \mathrm{hr}$ [processed 2.7 $\mathrm{kg}$ in $20 \mathrm{~min}(8.1 \mathrm{~kg} / \mathrm{hr})$ in a $108 \mathrm{~mm} \mathrm{ID} \mathrm{CCIM}=884.2 \mathrm{~kg} / \mathrm{m}^{2} / \mathrm{hr}$ ] [32]. Given this throughput and the known pounds per day required CCIM to complete the processing goal, a crucible with an inside diameter of at least 18.4 inches is required:

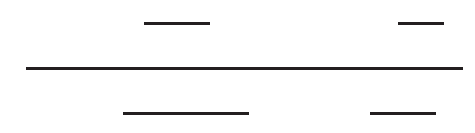

In a $50 \mathrm{~cm}$ diameter CCIM (Sugilal et. al., reported a glass melting rate of 20-40 kg/hr depending upon power input [18]. This gave a much lower throughput than that of Stefanovsky, at approximately 102 to 
$204 \mathrm{~kg} / \mathrm{m}^{2} / \mathrm{hr}$. Using this worst case scenario the required diameter would increase to $1.37 \mathrm{~m}$ or 54 inches.

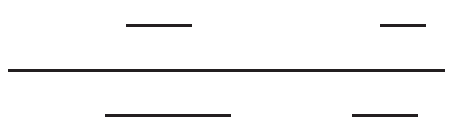

Kobelev and co-workers used the full scale, $41.8 \mathrm{~cm}$ inside diameter CCIM at the Radon facility in the former Soviet Union to examine the vitrification of SRS SBW at a high loading [31]. They were only able to achieve a specific glass production rate of $\sim 1085 \mathrm{~kg} / \mathrm{m}^{2} /$ day. Extrapolating this production rate to the diameter required to process 12.2 million pounds of calcine within timeline would require a diameter of approximately 81 inches $(206 \mathrm{~cm})$.

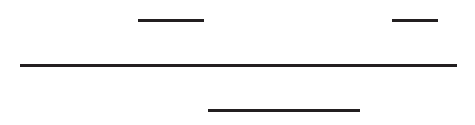

In another test with a new simulated waste and glass modifier at the same facility using the same size crucible Kobelev and co-workers were able to achieve a specific glass production rate of $2453 \mathrm{~kg} / \mathrm{m}^{2} /$ day [30]. If this specific productivity number to satisfy the calcine treatment requirements would require a crucible to be approximately $1.37 \mathrm{~m}$ (53.9 inches) inside diameter.

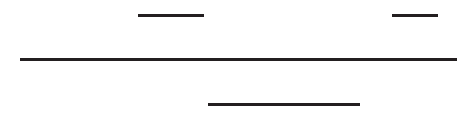

The tests conducted by Kobelev et al. [30, 31], highlight how different feed materials can greatly influence the throughput of the process and requires further investigation using the INL CCIM.

Given the variability seen in specific production rates it will be necessary to conduct tests to determine the nominal acceptable calcine throughput of the 10.25 inch diameter CCIM at INL. This number is required to properly size a full scale CCIM to achieve calcine processing goals and make economic comparisons with the HIP process as well as validate if sufficient CCIM foot print is available in the INL's IWTU. Depending upon throughput it may be possible to use a single CCIM system to meet production goals.

\subsubsection{Heating Schedule/Cooling Rates}

Heating schedules and cooling rates will have a significant effect on the waste form produced in the CCIM. Small scale tests with optimized glass additives yield "almost homogeneous glass" with traces of spinal type crystalline phase only observed at a waste loading of $60 \%$ [30]. They surmise that larger melt volumes in the CCIM may have caused increased crystallization, but it is also possible that differences in heating schedules for small-scale $(50 \mathrm{~mL})$ vs. large-scale pours differ, with the large-scale pour retaining heat longer, influencing crystallization. This point outs a significant challenge in scaling up, the importance of understanding how changes in parameters influence the waste form quality, and highlights a need to address questions related to cooling rates for the calcine/glass ceramic waste form post pour from the CCIM

As noted above, Day et al, evaluated 400 different formulation/cooling scenarios [23]. Their findings suggest that the formation of the major phases is not very sensitive to cooling rate once their 
ideal formulation was identified. However, to identify this set of cooling conditions many were tested for dropping the temperature from $1300^{\circ} \mathrm{C}$ to $\sim$ room temperature ranging from rapid quenching on a stainless steel plate to cooling at $\leq 24^{\circ} \mathrm{C}$. This approach should be repeated with the knowledge gained from the tests of Loiseau, Currant, and coworkers [8-12, 26, 27]. Their work suggests that a nucleation temperature of $1050^{\circ} \mathrm{C}$ held for $\sim 2$ hours will yield a consistently high crystal fraction with the vast preponderance being zirconolite. This should be used a starting point for studies exploring nucleation and crystal growth for forming the glass-ceramic calcine waste forms via the CCIM.

\subsubsection{Feed and Pouring Rates}

In the CCIM a fed-batch approach is assumed to be the mode of operation. In this case the material fed into the CCIM will be allowed to mix with melted material. After a set amount of time a portion of the well mixed glass will poured into waste canisters. After pouring the feed/pour cycle will continue.

Higher feed rates will lead the formation of a "cold cap" whereas lower feed rates will not. The cold cap could be used to reduce losses of volatile materials. Comparisons of the retained volatile material under feed rates that lead to cold cap vs. no cap should be evaluated.

Smith et al, tested the ability to maintain a cold cap a $500 \mathrm{~mm}$ ID CCIM operating at $1250^{\circ} \mathrm{C}$ at the NETEC facility in South Korea [33]. At a feed rate from 15 to 30 liters per hour approximately $60 \%$ coverage was preserved. At 50 liters/hour the cold cap coverage was $\sim 80 \%$. Higher feed rates were not tested due to increase pressure drop in the off-gas system causing the end of the demonstration. During the same demonstration pouring of the glass through the drain-discharge valve became more difficult with time, possibly due to crystallization of the melt within the drain valve. This highlights two potential problems that must be evaluated during testing.

\subsubsection{Canister size}

Several options are available for canister size, although it will be important to appropriately size the canister for the pouring rate. Given the size of our pilot scale CCIM is not practical to use standard 2' DOE canisters for testing. A smaller scale canister could be insulated such that it will have similar cooling characteristics as the standard 2' can. This canister should also allow for cooling along the centerline, i.e. Canister Centerline Cooling (CCC). Furthermore, the canister should be sufficiently tall enough to allow for multiple pours from the CCIM. This multiple pour test is more representative of the full scale version, where it is unlikely that a single pour will fill the standard 2' diameter can.

\subsection{Post Production Testing}

A standard suite of tests should be performed to analyze the quality of the waste forms produced during testing and to compare between different formulation and waste loadings. Product consistency testing (PCT) is designed to give normalized release values for the major components in the glass. This test will help determine how increased calcine loading influences the quality of the waste form and the maximum waste loading. Use of Scanning Electron Microscope with Energy Dispersive Spectroscopy (SEM-EDS) will allow for visualization of the different phases within the waste form as well as chemical characterization of these phases and should be used. This technique will allow for a compositional microanalysis of the crystalline phases and the surrounding glass. X-ray diffraction (XRD) should be used to garner information about the crystallographic structure and chemical composition of the waste form.

During testing of the CCIM several off-gas parameters should be closely monitored. These include off-gas flow rate and composition (especially for $\mathrm{Cr}, \mathrm{Cd}$, and $\mathrm{Hg}$ ) and particulate matter. A mass balance for $\mathrm{Cr}$ and $\mathrm{Cd}$ should be completed using the total scrubber water volume and composition and the 
composition of the waste form. This information will be used to validate the retention of volatiles within the waste form as well as ensure that the waste form not only immobilizes the radioactive constitutes of the calcine, but also meets RCRA requirements.

\section{Conclusions}

This report provides recommendations for the production of HLW calcine glass-ceramic waste forms using the CCIM located at INL. Glass-ceramics have several advantages over traditional borosilicate glasses as a waste form. By designing a glass-ceramic, the risks of deleterious effects from devitrification are removed; and glass-ceramics will provide a waste form with the advantages of both glass and ceramics: ease of manufacture with improved mechanical properties, higher waste loadings, thermal stability, and chemical durability.

This report does not recommend that any future research on pure glass formulations for the calcine waste forms should not be undertaken. Certainly the calcine compositions and the CCIM's increased temperature capability are well suited for making both borosilicate and phosphate based glass waste forms. However, our evaluations conclude that only the glass-ceramics can compete with the performance of the HIPing process and the glass-ceramic it produces. 


\section{References}

1. $\quad 75$ FR 137, 2010, "Amended Record of Decision: Idaho High-Level Waste and Facilities Disposition Final Environmental Impact Statement Revised by State 12/21/09." Federal Register, U. S. Department of Energy, 137-140, January 4, 2010

2. $\quad 75$ FR 1615, 2010, "Amended Record of Decision: Idaho High-Level Waste and Facilities Disposition Final Environmental Impact Statement; Correction." Federal Register, U. S. Department of Energy, 1615-1616, January 12, 2010

3. Balls, V.J. and R.C. Williams, Use of Existing IWTU Hot Cells for CDP HIP Treatment of HLW Calcine. 2011. Idaho Cleanup Project, RPT-785

4. Maio, V.C., Generalized Test Plan for the Vitrification of Simulated High-Level-Waste Calcine in the Idaho National Laboratory's Bench-Scale Cold Crucible Induction Melter. 2011. Idaho National Laboratory, INL/EXT-11-23231

5. Gombert, D. and J.R. Richardson, Cold-Crucible Induction Melter Design and Development. Nuclear Technology, 2003. 141(3): p. 301-308.

6. Soelberg, N., et al., ART CCIM Phase II-A Off-Gas System Evaluation Report. 2009. Idaho National Laboratory, INL/EXT-09-15711

7. Staiger, M.D. and M.C. Swenson, Calcined Waste Storage At The Idaho Nuclear Technology and Engineering Center. 2007. Idaho Cleanup Project, INEEL/EXT-98-00455 Rev. 3

8. Caurant, D., I. Bardez, and P. Loiseau, Crystallization of $\mathrm{CaHf}_{1}-\mathrm{XZr}_{x} \mathrm{Ti}_{2} \mathrm{O}_{7}(0 \leq x \leq 1)$ zirconolite in $\mathrm{SiO}_{2}-\mathrm{Al}_{2} \mathrm{O}_{3}-\mathrm{CaO}-\mathrm{Na}_{2} \mathrm{O}-\mathrm{TiO}_{2}-\mathrm{HfO}_{2}-\mathrm{ZrO}_{2}-\mathrm{Nd}_{2} \mathrm{O}_{3}$ glasses. Journal of Materials Science, 2007. 42(24): p. 10203-10218.

9. Caurant, D., et al., Effect of $\mathrm{Al}_{2} \mathrm{O}_{3}$ concentration on zirconolite ( $\mathrm{Ca}\left(\mathrm{Zr}, \mathrm{Hf}^{2} \mathrm{Ti}_{2} \mathrm{O}_{7}\right)$ crystallization in $\left(\mathrm{TiO}_{2}, \mathrm{ZrO}_{2}, \mathrm{HfO}_{2}\right.$ )-rich $\mathrm{SiO}_{2}-\mathrm{AlO}_{3}-\mathrm{CaO}-\mathrm{Na}_{2} \mathrm{O}$ glasses. Journal of Materials Science, 2007. 42(20): p. 8558-8570.

10. Caurant, D., et al., Crystallization of neodymium-rich phases in silicate glasses developed for nuclear waste immobilization. Journal of Nuclear Materials, 2006. 354(1-3): p. 143-162.

11. Loiseau, $\mathrm{P}$., et al., Crystallization study of $\left(\mathrm{TiO}_{2}, \mathrm{ZrO}_{2}\right)$-rich $\mathrm{SiO}_{2}-\mathrm{Al}_{2} \mathrm{O}_{3}-\mathrm{CaO}$ glasses Part I: Preparation and characterization of zirconolite-based glass-ceramics. Journal of Materials Science, 2003. 38(4): p. 843-852.

12. Loiseau, P., et al., Crystallization study of $\left(\mathrm{TiO}_{2}, \mathrm{ZrO}_{2}\right)$-rich $\mathrm{SiO}_{2}-\mathrm{Al}_{2} \mathrm{O}_{3}-\mathrm{CaO}$ glasses Part II: Surface and internal crystallization processes investigated by differential thermal analysis (DTA). Journal of Materials Science, 2003. 38(4): p. 853-864.

13. Donald, I.W., B.L. Metcalfe, and R.N.J. Taylor, The immobilization of high level radioactive wastes using ceramics and glasses. Journal of Materials Science, 1997. 32(22): p. 5851-5887.

14. Boatner, L.A. and B.C. Sales, Monazite, in Radioactive waste forms for the future, W. Lutze and R.C. Ewing, Editors. 1988, Elsevier Science Publishers: North-Holland, Amsterdam. p. 495-564.

15. Begg, B.D., et al. Low-risk waste forms to lock up high-level nuclear waste. in Waste Management Symposium. February 27 - March 3, 2005, Tucson, AZ.

16. Vienna, J.D., Nuclear Waste Vitrification in the United States: Recent Developments and Future Options. International Journal of Applied Glass Science, 2010. 1(3): p. 309-321.

17. Matyunin, Y.I. and S.V. Yudintsev, Immobilization of $\mathrm{U}_{3} \mathrm{O}_{8}$ in borosilicate glass in an induction melter with a cold crucible. Atomic Energy, 1998. 84(3): p. 173-178.

18. Sugilal, G., Experimental study of natural convection in a glass pool inside a cold crucible induction melter. International Journal of Thermal Sciences, 2008. 47(7): p. 918-925.

19. Sugilal, G. and P.B.S. Sengar. Cold Crucible Induction Melting Technology for Vitrification of High Level Waste: Development and Status in India. in Waste Management Symposium. February 24-28, 2008, Phoenix, AZ.

20. Hayward, P.J., Glass-ceramics, in Radioactive waste forms for the future, W. Lutze and R.C. Ewing, Editors. 1988, Elsevier Science Publishers: North-Holland, Amsterdam. p. 427-492. 
21. Donald, I.W., Immobilization by Vitrification, in Waste Immobilization in Glass and Ceramic Based Hosts: Radioactive, Toxic, and Hazardous Wastes. 2010. p. 121-177.

22. Ewing, R.C., The Design and Evaluation of Nuclear-Waste Forms: Clues from Mineralolgy. The Canadian Mineralogist, 2001. 39(3): p. 697-715.

23. Day, R.A., et al. Glass-Ceramics in a Cold-Crucible Melter: The Optimum Combination for Greater Waste Processing Efficiency. in Waste Management Symposium. February 23-27, 2003, Tucson, AZ.

24. Stefanovsky, S.V., B.S. Nikonov, and J.C. Marra, Characterization of the glass-ceramic material prepared upon vitrification of an iron-containing surrogate of high-level wastes in a cold crucible. Glass Physics and Chemistry, 2007. 33(6): p. 576-586.

25. Stefanovsky, S.V., et al., Influence of the content of radioactive wastes with high concentrations of aluminum, sodium, and iron oxides on the phase composition and structure of glassy materials prepared in a "cold crucible". Glass Physics and Chemistry, 2010. 36(4): p. 419-430.

26. Loiseau, P. and D. Caurant, Glass-ceramic nuclear waste forms obtained by crystallization of $\mathrm{SiO}_{2}-\mathrm{Al}_{2} \mathrm{O}_{3}-\mathrm{CaO}-\mathrm{ZrO}_{2}-\mathrm{TiO}_{2}$ glasses containing lanthanides (Ce, $\mathrm{Nd}, \mathrm{Eu}, \mathrm{Gd}, \mathrm{Yb}$ ) and actinides (Th): Study of the crystallization from the surface. Journal of Nuclear Materials, 2010. 402(1): p. 38-54.

27. Loiseau, P., et al., Glass-ceramic nuclear waste forms obtained from $\mathrm{SiO}_{2}-\mathrm{Al}_{2} \mathrm{O}_{3}-\mathrm{CaO}-\mathrm{ZrO}_{2}-\mathrm{TiO}_{2}$ glasses containing lanthanides (Ce, $\mathrm{Nd}, \mathrm{Eu}, \mathrm{Gd}, \mathrm{Yb}$ ) and actinides (Th): study of internal crystallization. Journal of Nuclear Materials, 2004. 335(1): p. 14-32.

28. Idaho, 1995. Settlement Agreement, State of Idaho, Department of Energy, and Department of the Navy, to resolve all issues in Public Service Co. of Colorado v. Batt, CV-91-0035-S-EJL (D. Id.) and United States v. Batt, No. CV-91-0065-S-EJL (D. Id.), U. S. District Court of Idaho, dated October 16, 1995.

29. DOE-ID, 2009. Modification No. 104, Section C.2.8.2 "High Level Waste (HLW) Calcine," Idaho Cleanup Project (ICP) Cost-Plus-Incentive-Fee (CPIF) Contract with CH2M-WG Idaho, LLC., Contract DE-AC07-05ID14516, U. S. Department of Energy Idaho Operations Office, August 10, 2009.

30. Kobelev, A.P., et al., Full-Scale Cold Crucible Test on Vitrification of Savannah River Site SB4 $H L W$ Surrogate, in Environmental Issues and Waste Management Technologies in the Materials and Nuclear Industries XII, A. Cozzi and T. Ohji, Editors. 2009, John Wiley \& Sons, Inc.: Hoboken, NJ. p. 9-20.

31. Kobelev, A.P., et al., Cold crucible vitrification of the Savannah River Site SB2 HLW surrogate at high waste loading. Glass Technology - European Journal of Glass Science and Technology Part A, 2008. 49(6): p. 307-312.

32. Stefanovsky, S.V., et al., Inductive cold crucible melting of actinide-bearing murataite-based ceramics. Journal of Alloys and Compounds, 2007. 444-445: p. 438-442.

33. Smith, M.E., et al., NETEC Cold Crucible Induction Melter Demonstration for SRNL with Simulated Sludge Batch 4 DWPF Waste, in Environmental Issues and Waste Management Technologies in the Materials and Nuclear Industries XII, A. Cozzi and T. Ohji, Editors. 2009, John Wiley \& Sons, Inc.: Hoboken, NJ. p. 29-37. 